\title{
Azoospermia of Dogs with Apoptotic Germ Cells and Leydig Cells
}

\author{
Eiichi KAWAKAMI, Tatsuya HORI and Toshihiko TSUTSUI \\ Department of Reproduction, Nippon Veterinary and Animal Science University, 1-7-1 Kyonan-cho, Musashino-shi, Tokyo 180-8602, \\ Japan
}

(Received 29 June 1999/Accepted 6 December 1999)

ABSTRACT. Apoptotic cell death in the testes of 4 dogs with azoospermia was examined. Blood plasma luteinizing hormone (LH), testosterone $(\mathrm{T})$, and estradiol-17 $\beta\left(\mathrm{E}_{2}\right)$ concentrations, and testicular transferrin (Tf) concentration as a marker of Sertoli cell function were measured in the 4 azoospermic dogs and in 5 normal dogs. The spermatids in 2 of the 4 azoospermic dogs and the Leydig cells in 3 of them exhibited apoptotic cell death. Mean $\mathrm{LH}, \mathrm{E}_{2}$, and Tf concentrations in the 4 azoospermic dogs were significantly higher than in the normal dogs $(\mathrm{P}<0.01)$. These findings suggested that the azoospermia in all 4 dogs might has been caused by abnormal functions of Sertoli cells as well as Leydig cells.-KEY WORDS: apoptosis, azoospermia, canine.

J. Vet. Med. Sci. 62(5): 529-531, 2000

Apoptotic germ cells have been observed in the human testes with spermatogenic dysfunction [23]. In mice and rats, apoptosis of germ cells was described with artificial cryptorchidism [9, 20], and after long-term treatment with Gn-RH agonist [4], or with chemicals suppressing testosterone $(\mathrm{T})$ secretion [22], as well as after injection of estradiol-17 $\beta\left(\mathrm{E}_{2}\right)$ [5]. In canine species, the cause of infertility mostly remains unknown $[8,17]$, although spermatogenic dysfunction due to orchitis [3], or poor secretion of the anterior pituitary gland or testis [13] has been observed in some cases. This study focused on apoptotic cells in the testis of azoospermic dogs in relation to blood levels of luteinizing hormone ( $\mathrm{LH}), \mathrm{T}$, and $\mathrm{E}_{2}$. The concentrations of testicular transferrin ( $\mathrm{Tf}$ ) were also measured as a marker of Sertoli cell function $[12,16]$.

Four azoospermic dogs, 3 Beagles and a Shetland Sheepdog, aged 3-6 years, were used in this study. They were receiving care at our university and were selected on the basis of 3 semen collections and evaluations. The parents of the 3 male Beagles were different and they have had no experience of any chemical treatments. Under halothane anesthesia, testicular tissue was biopsied from the 4 azoospermic dogs and 3 normal Beagle dogs, and fixed in Bouin's solution. Paraffin sections $3 \mu \mathrm{m}$ in thickness were made and stained with PAS-hematoxylin. The other sections were washed in butanol and examined for apoptosis of germ, Sertoli and Leydig cells using a kit
(Trevigen, Inc., USA) for the detection of free 3'-hydroxyl residues resulting from DNA fragmentation initiated by streptavidin-horseradish peroxidase (TUNEL method). Apoptotic cells in 500 specific cells were counted.

The concentrations of $\mathrm{LH}, \mathrm{T}$, and $\mathrm{E}_{2}$ were measured by radioimmunoassay of peripheral blood plasma from the 4 azoospermic and 5 normal dogs, as described previously $[14,15,26]$. The biopsied testicular tissues were examined for Tf concentrations by enzyme immunoassay [12]. All the data were statistically analyzed by Student's $t$-test.

Spermatogonia and spermatocytes were observed in the seminiferous tubules in all the azoospermic dogs (Table 1). Although round spermatids were seen in the tubules of 2 (Dogs No.2 and 4) of the 4 azoospermic dogs, no spermatozoa were found in any of the dogs. About $3 \%$ of round spermatids were apoptotic (Table 1 and Fig. 1-a). In 3 (Dogs No. 1, 2 and 4) of the 4 azoospermic dogs, about 3 to $8 \%$ of the Leydig cells exhibited apoptotic death (Table 1 and Fig. 1-b). No apoptosis was seen in Sertoli cells in any of the dogs with azoospermia. Apoptotic cells were not detected in the testes of the 3 normal dogs.

In the dogs with azoospermia, the mean plasma levels of LH and $E_{2}$ as well as testicular Tf showed significantly higher concentrations than in the normal dogs $(\mathrm{P}<0.01)$, whereas the plasma $\mathrm{T}$ concentrations were significantly lower $(\mathrm{P}<0.01)$ (Table 2). The mean hormone levels of Dog No. 3 which showed no apoptosis in the testes (Table 1)

Table 1. Testicular histology of 4 dogs with azoospermia and 3 normal dogs

\begin{tabular}{lcrc}
\hline $\begin{array}{l}\text { Dog No. } \\
\text { (Breed) }\end{array}$ & $\begin{array}{c}\text { Germ cells }{ }^{\text {a) }} \text { observed } \\
\text { in seminiferous tubules }\end{array}$ & $\begin{array}{c}\text { Apoptotic } \\
\text { germ cells } s^{\mathrm{a}, \mathrm{b})}\end{array}$ & $\begin{array}{c}\text { Apoptotic } \\
\text { Leydig cells }\end{array}$ \\
\hline 1 (Beagle) & S and P & $0.0 \%$ & $8.2 \%$ \\
2 (Beagle) & S, P, and R & R: $3.4 \%$ & $2.8 \%$ \\
3 (Beagle) & S and P & $0.0 \%$ & $0.0 \%$ \\
4 (Shetland sheepdog) & S, P, and R & R: $2.6 \%$ & $3.6 \%$ \\
Normal beagles & S, P, and R & $0.0 \%$ & $0.0 \%$ \\
\hline
\end{tabular}

a) S: spermatogonia, P: primary spermatocytes, R: round spermatids.

b) The percentages of apoptotic cells in 500 cells. 

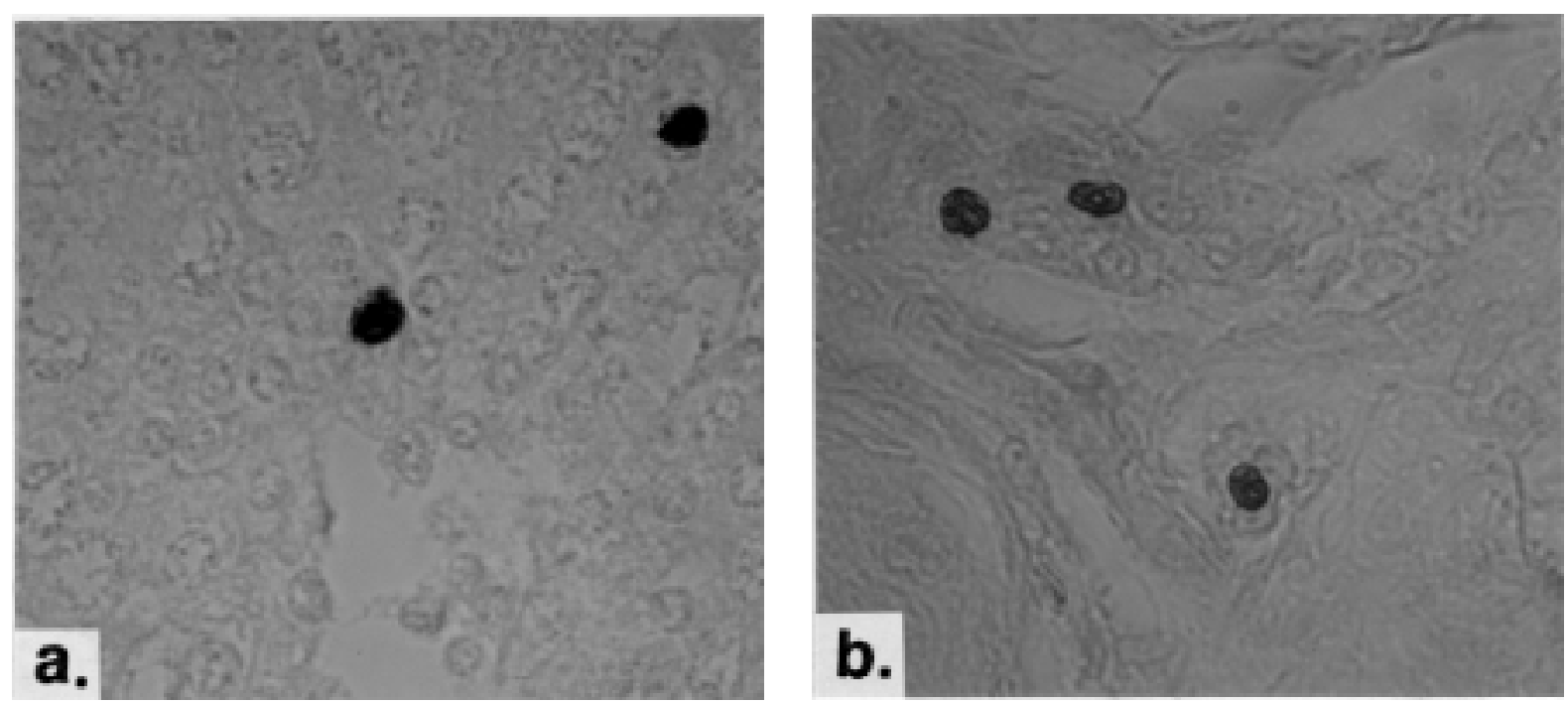

Fig. 1. Round spermatids (a) and Leydig cells (b) exhibiting apoptosis in Dog No.4 with azoospermia. Condensation of nuclear chromatin of round spermatids and Leydig cells exhibiting apoptosis (arrows). TUNEL method. $\times 400$.

Table 2. Mean ( \pm S.E.) concentrations of peripheral plasma luteinizing hormone $(\mathrm{LH})$, testosterone $(\mathrm{T})$, and estradiol- $17 \beta\left(\mathrm{E}_{2}\right)$ and testicular transferrin (Tf) in 4 dogs with azoospermia and 5 normal Beagle dogs

\begin{tabular}{lllll}
\hline Dogs & $\mathrm{LH}(n \mathrm{~g} / \mathrm{m} l)$ & $\mathrm{T}(n \mathrm{~g} / \mathrm{m} l)$ & $\mathrm{E}_{2}(\mathrm{gg} / \mathrm{m} l)$ & $\mathrm{Tf}(\mathrm{ng} / \mathrm{mg})$ \\
\hline Azoospermia & $13.2 \pm 1.1^{*}$ & $1.0 \pm 0.5^{*}$ & $25.5 \pm 2.7^{*}$ & $499.0 \pm 41.1^{*}$ \\
Normal & $5.4 \pm 0.6$ & $2.7 \pm 0.3$ & $11.8 \pm 1.2$ & $307.4 \pm 25.7$
\end{tabular}

* $\mathrm{P}<0.01$, in comparison with normal dogs.

were similar to the values in the other azoospermic dogs. High testicular Tf concentrations were found in the 4 azoospermic dogs, suggesting on abnormally enhanced function of Sertoli cells, which are known to produce high levels of $E_{2}[6,19]$, and to control Leydig cell functions by a paracrine effect $[7,24]$. High concentration of plasma $E_{2}$ might also inhibit $\mathrm{T}$ secretion from the testis [11], possibly inducing apoptotic death of germ cells [5]. After $\mathrm{E}_{2}$ injection, spermatids and spermatozoa were reported to disappear in the seminiferous tubules of bulls [18] and atrophy was induced in the testes of dogs [10]. Apoptosis of spermatids and Leydig cells observed in the present study, was considered to result from the high level of $E_{2}$ secreted by the Sertoli cells.

In hypophysectomized adult rats, no apoptosis was described as appearing in Sertoli or Leydig cells [4]. As apoptosis of Leydig cells has not been reported in any animal species, the apoptosis of Leydig cells observed in this study might be related with spermatogenic dysfunction under lowered $\mathrm{T}$ secretion due to enhanced $\mathrm{E}_{2}$ secretion by Sertoli cells. Since T secretion by Leydig cells is known to stimulate the latter half stage of spermatogenesis [21], the apoptosis of spermatids might result from not only high $E_{2}$ levels but also low T levels. The apoptosis of spermatogonia was observed in the seminiferous tubules of normal rats [2], but no apoptosis of germ cells was detectable in any of the 3 normal dogs in this study.

There have been a few reports of abnormally high plasma $\mathrm{LH}$ and $\mathrm{E}_{2}$ levels in azoospermic human patients [1, 25]. The high plasma LH concentrations in the 4 azoospermic dogs were thought to be induced by a positive feed-back mechanism of the hypophyse-gonadal axis after lowered $\mathrm{T}$ secretion of the Leydig cells.

These findings suggested that the azoospermia of the 4 dogs might have been the result of abnormally functioning Sertoli cells as well as Leydig cells.

\section{REFERENCES}

1. Aiman, J. and Griffin, J.E. 1982. J. Clin. Endocrinol. Metab. 54: 725-732.

2. Allan, D.J., Harman, B.V. and Kerr, J.F.R. 1987. pp. 229258. In: Perspectives on mammalian cell death (Potten, C.S. ed.), Oxford Univ. Press, London.

3. Allen, A.E. and Patel, J.R. 1982. J. Small Anim. Pract. 23: 713-718.

4. Billig, H., Furuta, I., Rivier, C., Tapanainen, J., Parvinen, M. 
and Hsueh, J.W. 1995. Endocrinology 136: 5-12.

5. Blanco-Rodriguez, J. and Martinez-Garcia, C. 1997. J. Reprod. Fertil. 110: 61-70.

6. Dorrington, J.H., Fritz, I.B. and Armstrong, D.T. 1978. Biol. Reprod. 18: 55-64.

7. Dufau, M.L., Hseuh, A.J., Cigorraga, S., Baukal, A.J. and Catt, K.J. 1978. Int. J. Androl. (Suppl.) 2: 193-239.

8. Evans, J. and Renton, J.P. 1973. Vet. Rec. 92: 198-199.

9. Ito, K., Tanemura, K., Gotoh, H., Kurohmaru, M. and Hayashi, Y. 1997. J. Vet. Med. Sci. 59: 353-359.

10. Jabana, A.G. 1962. Austral. J. Exp. Biol. 40: 293-308.

11. Kalla, N.R., Nisula, B.C., Menard, R. and Loriaux, D.L. 1980. Endocrinology 106: 35-39.

12. Kawakami, E., Arai, T. and Oishi, I. 1999. Int. J. Androl. 22: 224-228.

13. Kawakami, E., Hori, T. and Tsutsui, T. 1997. Anim. Reprod. Sci. 47: 157-167.

14. Kawakami, E., Tsutsui, T. and Ogasa, A. 1990. Jpn. J. Vet. Sci. 52: 179-181.

15. Makino, T., Inano, K., Yoshida, T., Den, N., Takagi, S. and Kanbegawa, A. 1973. Clin. Endocrinol. (Tokyo) 21: 867-873 (in Japanese).

16. Nanbu, A. and Kumamoto, Y. 1995. Jpn. J. Urol. 86: 1221-
1230 (in Japanese with English summary).

17. Oettle, E.E. and Soley, J.T. 1985. J. S. Afr. Vet. Assoc. 56: 103-106.

18. Ogasa, A., Sugawa, Y. and Matsuyama, S. 1963. Jpn. J. Anim. Reprod. 9: 12-16 (in Japanese with English summary).

19. Rommerts, F.F.G., DeJong, F.H., Brinkmann, A.O. and Van der Molen, H.J. 1982. J. Reprod. Fertil. 65: 281-288.

20. Shikone, T., Billig, H, and Hsueh, A.J.W. 1994. Biol. Reprod. 51: 865-872.

21. Steinberger, E. and Duckett, G.E. 1967. J. Reprod. Fertil., (Suppl. )2: 75-87.

22. Troiano, L., Faustini Fustini, J.L., Lovato, E., Frasoldati, A., Malorni, W., Capri, M., Grassili, E., Marrama, P. and Franceschi, C. 1994. Biochem. Biophys. Res. Commun. 202: 13151321.

23. William, W.L., Larry, I.L., Dolores, J.L., Edward, D.K. and Thomas, M.W. 1997. Fertil. Steril. 68: 1065-1069.

24. Wu, N. and Murono, E.P. 1996. Andrologia 28: 247-257.

25. Wu, F.C.W., Swanston, I.A. and Baird, D.T. 1982. Clin. Endocrinol. 16: 39-47.

26. Yoshida, T., Den, N., Ozaki, H., Takagi, S., Makino, T. and Kanbegawa, A. 1973. Clin. Endocrinol. (Tokyo) 21: 651-656 (in Japanese). 